\title{
VANAD UUENDUSED LÕUNA- JA PÕHJAEESTI KEELES ${ }^{1}$
}

\author{
KRISTIINA ROSS
}

\begin{abstract}
Annotatsioon. Artiklis analüüsitakse saksapärase saama + Sup -tuleviku esinemist eesti vanema kirjakeele tartu ja tallinna variandis. Kirjeldatakse lähemalt selle saatust XVII sajandi lõpukümnendite kirjakeele reformi käigus ning visandatakse punktiirselt tarindi hilisem kasutuslugu XVIII sajandi ja XIX sajandi esimese poole olulisemate autorite keeles. Selgub, et kuigi põhjaeesti piiblikeelest kaotati saama + Sup -tulevik XVII sajandi lõpus peaaegu täielikult ning ka XVIII sajandi autorid hoidusid selle tarvitamisest, püsis see lõunaeesti piiblikeeles kogu aeg aktiivselt kasutusel (kuni tartu keele lõpliku hääbumiseni XX sajandi alguses). Põhjaeesti ilmalikus keeles võeti saama + Sup -tulevik XIX sajandil uuesti tarvitusele, kusjuures eriti jõuliselt hakkasid seda rakendama just rahvuslikult meelestatud ja hea eesti keele oskusega autorid. Artiklis jõutakse tõdemusele, et XVII sajandi lõpul võis saama + Sup -tuleviku erineva kohtlemise põhjuseks olla keeleuuendajate teadlik otsus, mis lähtus Põhja- ja Lõuna-Eesti murrete erinevusest, kuid niisuguse oletuse tõestamine või ümberlükkamine vajaks murdematerjali detailsemat analüüsi. Sest sama hästi võis saama + Sup -tuleviku erinev käekäik kahes kirjakeele variandis tuleneda lihtsalt sellest, et idee loobuda võõrmõjuliseks peetavast väljendusviisist tekkis keeleuuendajatel tartu keele jaoks liiga hilja, siis kui selle etalontekst „Wastne Testament” oli juba ilmunud ja omaks võetud.
\end{abstract}

Võtmesõnad: kirjakeele ajalugu, tartu keel, tallinna keel, futuurum

\section{XVII sajandi keeleuuendus lõuna- ja põhjaeesti keeles}

Keeleuuenduse all peetakse eesti kultuuriloos tavaliselt silmas XX sajandi alguses toimunud uuendamislainet, mis seostub eeskätt Johannes Aaviku nimega. Kuid kirjakeele arengus on olnud teisigi aegu, mil suhteliselt

\footnotetext{
1 Artikli aluseks on Huno Rätsepa juubelikonverentsil „Keeleuuenduse aastasada" 28.12.2012 peetud ettekanne. Uurimistööd on rahastanud ETF 7896 ja SF0050037s10.
} 
lühikese aja jooksul sihipäraselt ellu viidud reformide tulemusel on maksvusele pääsenud varasemast oluliselt erinev keelevariant. Üks selline ajalõik oli XVII sajandi viimane veerand, mil tegeldi intensiivselt piibli tõlkimisega põhja- ja lõunaeesti keelde ehk tallinna ja tartu keelde, nagu neid keelevariante vastavate keskuste järgi nimetatakse. Tõlke- ning keeleküsimustes kujunes Eestimaa ja Liivimaa konsistooriumi ringkondades välja kaks vastandlike vaadetega koolkonda. Eestimaalased, kes tõlkisid piiblit tallinna keelde, kasutasid sihtkeelena sajandi esimesel poolel tekkinud saksapärast keelevarianti. Liivimaa koolkonna esindajad, kes tegelesid nii tartu- kui ka tallinnakeelse tõlke arendamisega, pooldasid sihtkeelte rahvapärastamist. 1686. aastal ilmus Liivimaa konsistooriumi tõlkijate, eeskätt Andreas ja Adrian Virginiuse tööna tartukeelne „Wastne Testament", mille keel oli võrreldamatult ladusam ja rahvapärasem kui pool sajandit varem Joachim Rossihniuse perikoopidega kehtestatud tartu keele variant (Peebo 2001). Samavõrra värskendavalt uuenduslik oli see ka tollaste tallinnakeelsete perikoobiraamatute ja käsikirjaliste tõlgetega võrreldes. Nüüd puhkesid tallinnakeelse trükikõlbliku tõlke üle tulised vaidlused ja korraldati tõlkekonverentse, sest liivimaalased soovisid reformida ka tallinna keelt (Pahtma, Tafenau 2003; Tafenau 2011). Eestimaalaste konservatiivne tõlkeversioon on säilinud nn Pilistvere käsikirjas (vt lähemalt Tafenau 2007), keeleuuendajate tööd esindab 1694. aastast pärit koopia, mida peetakse üsna täpseks ärakirjaks versioonist, mille Johann Hornung pani kirja 1687/1688. aasta sügistalvel (vt lähemalt Reila 2007). Mõningase kohendamise järel ilmus uuenduslik versioon viimaks 1715 . aastal ning jõudis siis pärast veelkordset toimetamist lõpuks, 1739. aastal, ka esimesse trükitud täispiiblisse. Huvitavat põhjaeesti keele varianti esindab oletatavasti samast reformide ajast pärit vana testamendi tõlge, mida peetakse Andreas ja Adrian Virginiuse tõlke veidi hilisemaks koopiaks (vt lähemalt Ross 2003).

Niisiis võib XVII sajandi lõpukümnendite puhul rääkida (pisut tinglikult) neljast näidistekstist: konservatiivne tallinnakeelne Pilistvere käsikiri (Pilistvere 1680-1687), keeleuuenduse tartukeelne etalontekst „Wastne Testament" (WT 1686), uuenduslik tallinnakeelne uue testamendi tõlge Müncheni käsikirja näol (München 1694), uuenduslik tallinnakeelne vana testamendi tõlge Virginiuste tõlke koopia näol (Virginiused 1687-1690).

Müncheni käsikirja ehk Johann Hornungi tõlke oletatava koopia võrdlus ühelt poolt Pilistvere käsikirjaga, teisalt „Wastse Testamendiga” 
veenab, et tallinna keeles toimus XVII sajandi 80. aastate lõpul reform, mille käigus kirjakeelt oluliselt degermaniseeriti ja rahvapärastati, ning et tartukeelse „Wastse Testamendi” eeskuju mängis selles reformis tähtsat osa. Sedakaudu on tartu keel mõjutanud kogu hilisemat põhjaeestilist kirjakeelt (Laanekask 2003: 125). Selle üle, mis tallinna keelest edasi sai, võib nüanssides vaielda: kas 1739. aasta piiblitõlge oli Hornungist sammuke tagasi, nagu Eduard Ahrens väidab, või mitte - aga üldine suundumus on üheselt selge.

Hornungist ja tema mõttekaaslastest alguse saanud tallinna keel püsis terve XVIII sajandi ja hakkas omakorda uuenema alles XIX sajandi alguses. Kiriku- ja piiblikeelena püsis see kauemgi, kuid XIX sajandil hakkas ilmalik keel rahvuslikult meelestatud literaatide loomingus omapäi, kirikukeelest sõltumatuna, edasi arenema. Reformitud tartukeelne „Wastne Testament" säilitas oma keelelise ilme üsna muutumatul kujul kuni viimase trükini 1905. Omaette ilmalikku ilukirjanduslikku registrit tartu keeles XIX sajandil välja ei kujunenud, sest rahvusliku konsolideerumise käigus mindi üle ühtsele, põhjaeestilisele kirjakeelele.

\section{2. saama-tulevik kummaski kirjakeeles XVII-XIX sajandil}

Visandatud arengukäikude taustal mõjub ootamatuna saama-tuleviku käekäik kummaski kirjakeeles. Abiverbist saama ja põhiverbi supiinist koosnev saama-tulevik (saama + Sup -tulevik) kopeerib täpselt (ülem)saksa werden-tulevikku (ich werde lesen $\rightarrow$ mina saan lugema) ning seetõttu peetakse seda laenuliseks võõrkonstruktsiooniks, ehkki ka n-ö ehedast läänemeresoomelisest keeleainesest võib leida lähedasi tarindeid (Mägiste 1936; Metslang 1994; Tragel, Habicht 2012). Eesti kirjakeeles muutus seesugune saama-tulevik tavaliseks XVII sajandi esimesel poolel. XVI sajandi üle otsustamiseks pole säilinud piisavalt keelematerjali, kuid arvata võib, et sellal domineeris alamsaksapärane tava, milles tulevikku väljendati abiverbide tahtma ja pidama kaasabil. Tallinna keeles kasutas Georg Müller igatahes veel XVII sajandi alguses niisugust alamsaksapärast tulevikku, kuid 1630. aastatel ilmunud käsiraamatutes rakendati nii tallinna kui ka tartu keeles juba saama + Sup -tulevikku, nt Lk 10:28 mõlemas variandis saht ellama (Stahl 1638; Rossihnius 1632). Tallinnakeelses kirjanduses püsis saama + Sup -tulevik XVII sajandi 80. aastateni (Lk 10:28 saht ellama-Pilistvere 1680-1687). Ka XVII sajandi 
keskpaiga lõunaeesti keele olulisim autor Johannes Gutslaff kirjeldas oma grammatikas seesugust tulevikukonstruktsiooni (Gutslaff 1998 (1648): 111), ehkki oma praktilises tõlkekeeles eelistas ta tulevikutarindis enamasti $m a$-tegevusnimele $d a$-tegevusnime (Lk 10:28 saht ellada-Gutslaff 1647-1657; vt lähemalt Ross 2013: 478-479).

XVII sajandi lõpul läks aga tallinna keel selle konstruktsiooni puhul tartu keelest uuendustega ette. Keeleuuenduse etalonis, tartukeelses ,Wastses Testamendis", oli saama + Sup -tulevik endiselt tavaline väljendusviis (vrd seesama Lk 10:28 saht ellämä - WT 1686) ning tartu kirikukeelde jäigi saama-tulevik püsima. Samasugust tulevikku kasutas XVIII sajandi Iõpu autor Heinrich Andreas Erxleben ka oma vana testamendi lühendatud tõlkes. Erxleben rakendas saama + Sup -tarindit isegi oma väljaande neis põhjaeestikeelse trükipiibli järgi sõnastatud osades (vt lähemalt Ross 2011), kus trükipiiblis esineb tuleviku tähenduses oleviku vorm või konstruktsioon abiverbiga pidama. Nt Ii 5:19 Kue ahhastusse seest peästab ta sind ärra, ja kui seitsmes kä, ei pea ei middagi kurja sinnusse puutma (Piibel 1739) $\rightarrow$ Kuus Willitsusse sissest saap temmä sinno ärräpästmä, nink kui säitsmes käen: sis ei sa middäke kurja sinno putma (Erxleben 1796). Tartukeelsetes uue testamendi väljaannetes püsib saama + Sup -tulevik kuni viimase trükini 1905. aastal muutumatuna ka kirjakohtades, kus selle järjekindel rakendamine lause eriti lohisevaks teeb, nagu nt Jh 16:13-14 Ent kui temä saap tulema, tõisiduse Waim, sis saap temä teid kõige tõte sisse juhatama; sest temä ei saa mitte esi hendäst kõnelema, enge mis temä saap kuulma, sedä saap temä kõnelema, nink mis tullew om, teile kuulutama. Temä saap minno ärä seletämä, sest mino omast saap temä wõtma, nink teile kuulutama (WT 1905).

Tallinna keelest aga kõrvaldati saama + Sup -tulevik keeleuuenduse käigus peaaegu täielikult. Oletatavasti ainult aasta-poolteist pärast tartukeelse „Wastse Testamendi” ilmumist valminud tallinnakeelse tõlke veidi hilisemas koopias on saama-tulevikust enamasti loobutud (Lk 10:28 ellad - München 1694). Johann Hornung kirjutas ka oma grammatikas otsesõnu, et eesti keeles eraldi tulevikuaeg puudub ning tuleviku tähenduses kasutatakse olevikuvormi, tahtma-konstruktsiooni või muid leksikaalseid vahendeid (Hornung 1977 (1693): 73). Uuenduslikus tallinnakeelses tõlkes tarvitatakse tuleviku tähenduses enamasti kindla kõneviisi olevikuvormi või pidama-konstruktsiooni (Kilgi 2010: 168-169). Selline ajakasutus iseloomustab ka 1739. aasta täispiiblit. Seal rakendati (pidama- 
-tulevikule lisaks) eriti ohtralt abiverbi saama ja põhiverbi mineviku kesksõna ühendit (saab teinud/tehtud) ehk saama + Pts -tarindit, milles abiverb võib olla ka mineviku vormis ning mille tähendus on resultatiivne. Tuleviku tähenduses saama + Sup -tarindite kasutamist püüti ilmselgelt vältida. Täispiibli vana testamendi toimetamisel redigeeris Anton Thor Helle saama + Sup -vormid sihikindlalt välja (Kilgi 2011: 98-99) ning trükiversiooni on neid jõudnud vaid üksikuid.

Tallinna keeles näib saama + Sup -tulevik olnuvat põlu all terve XVIII sajandi. ${ }^{2}$ Isegi sajandi lõpu jutukirjanikud, saksa keele eeskuju austav F. G. Arwelius (Kask 1970: 102) ja paiguti lausa vigaselt võõrapärase lausestusega R. W. Willmann (Kask 1970: 104) vältisid seda ning nende keeles esineb tuleviku tähenduses pidama-konstruktsioon. Tallinnakeelsetest tekstidest õnnestus leida ainult üks tulevikuline saama + Sup -tarind (,Köki ja Kokka Ramat”: saab käima), ehkki saama + Pts -tarindeid leidub kõikides tekstides hulgi. Samaaegsetes tartukeelsetes tekstides esineb aga kõigis (partitsiipsetele tarinditele lisaks) vähemalt mõni saama + Sup -tulevik ${ }^{3}$, nt sawa piddama (F. D. Lenz), sawa tullema (J. C. Quandt), sawa ellämä (A. Raudiall).

Niisugune pilt vastab hästi A. W. Hupeli grammatika kirjeldusele. Nimelt räägib Hupel oma 1780. aastal ilmunud grammatikas saama-tulevikust tallinna ja tartu keele puhul erinevat juttu. Tallinna keele osas ütleb Hupel (J. Hornungi ja A. Thor Helle jälgedes) otse, et eesti keeles tulevik puudub ning seda võib väljendada erineval viisil. Ühe võimalusena mainib ta küll ka malli saama + Sup (Hupel 1780: 38), kuid näidisparadigmas jätab ta kindla kõneviisi tuleviku lihtsalt välja ning esitab konjunktiivi futuurumi nime all ainult saama + Pts -konstruktsioonid (saan valmistanud - Hupel 1780: 46). Tartu murdes seevastu kirjeldab ta (J. C. Clare käsikirjalise grammatika jälgedes) saama + Sup -tulevikku täiesti tavalise

2 Väide tugineb peale kirikukirjanduse ka 2013. a märtsis VAKKUR-is kasutada olnud teostele: F. G. Arwelius „Üks kaunis Jutto ja Öppetusse-Ramat”, 1782; N. V. Hagemeister „Lühhikene öppetus maa rahwale”, 1796; A. W. Hupel „Lühhike Öppetus”, 1766-1767, „Arsti Ramat”, 1771; J. Lithander „Köki ja Kokka Ramat”, 1781; R. W. Willmann ,Juttud ja Teggud”, 1782. Nagu teada, hilisemates töödes vähemalt Arweliuse keeletarvitus muutus (Kask 1970: 103) ning see võib puudutada ka tulevikutarindeid.

3 Üldistus on tehtud VAKKUR-is 2013. a märtsis kasutada olnud teoste põhjal: J. C. Quandt „Kolm kaunist Waggaause Eenkojut”, 1776; F. D. Lenz „Aija-Kalender”, 1796; A. Raudiall „Ütte wanna Jesusse Teenre”, 1792. 
moodustusviisina ja esitab selle näidisparadigmas täieõigusliku liitvormina (minna sa armastama - Hupel 1780: 63, 71).

XIX sajandi esimesel poolel, mil tartukeelseid uusi tekste enam kuigi palju juurde ei tekkinud (Laanekask 2001: 125-129), toimus ühiseks kirjakeeleks kujuneva tallinna keelega tekstides uus muutus: saama + Sup -tulevik võeti taas kasutusele, kusjuures torkab silma, et selle agarate tarvitajate hulgas leidub palju rahvuslikult meelestatud ning eesti emakeelega või vähemalt eestikeelse tagapõhjaga autoreid. Näiteks Kristjan Jaak Peterson kasutas saama + Sup -tulevikku nii proosatekstis kui ka koguni oma luules ( $\underline{\text { Savad }}$ iggaveste / Minnule paistamaie / Armsa Allo silmad! - IAAK 2001: 55). Eriliselt näib saama + Sup -tulevikku armastanuvat F. R. Kreutzwald, kuid tema kõrval tarvitasid seda vana kirjakeele korpuses leiduvatest autoritest ${ }^{4}$ veel O. W. Masing, O. R. von Holtz, Suve Jaan, A. Umblia, J. Schwelle, G. H. Schüdlöffel, C. Kersten ja „Mai Roosi” tõlkija. J. W. L. von Luce paistab tuleviku tähenduses kasutanuvat $d a$-infinitiiviga konstruktsiooni (nt siis saab teie kässi heästi käja siin, ja seäl teises ilmas). saama + Sup -tulevikku ei esine C. W. Freundlichi, K. Jordani, G. M. Knüpfferi, P. von Manteuffeli ega C. J. Masingu korpusetekstides.

Põhjaeesti piiblitõlkesse muidugi saama + Sup -tulevikku tagasi tooma ei hakatud. Nii oli Eduard Ahrensi poolt iganenult saksapäraseks

${ }^{4}$ Märtsis 2013 olid VAKKUR-is saadaval: C. W. Freundlich „Pöllomehhe ait”, 1849; O. R. von Holtz „Luggemissed Eestima Tallorahwa moistusse ja süddame juhhatamisseks”, 1817; K. Jordan (tlk) „Lambrise-Ramat”, 1840; G. M. Knüpffer „Öppetusse ramat Saksama lamba-karjastele”, 1837; C. Kersten (tlk) „Peegel Jummala rigi leikusse tööst”, 1847; F. R. Kreutzwald „Wina-katk”, 1840; „Ue aasta sowimine”, 1843a; „Reinowadder Rebbane”, 1850a; „Ma- ja Merre-piltid”, 1850b; „Sippelgas”, I 1843b, II 1861; J. W. L. von Luce „Sarema Jutto Ramat”, I 1807, II 1812; P. von Manteuffel „Aiawite peergo walgussel”, 1838; C. J. Masing „Monned Kennad Luggud töeste sündinud asjadest, Ma-rahwa mele heaks ja hinge kassuks kokkukirjotud”, 1839; O. W. Masing „Ehstnische Originalblätter für Deutsche”, 1816; „Pühhapäwa Wahhe-luggemissed”, 1818; „Jutlus mis Priusse kulutamisse päwal”, 1820; G. H. Schüdlöffel (tlk) „,Peter Pung, kaewandaja poeg”, 1843; , ,Toomas Westen, Lapo rahwa uso ärataja Norra maal”, 1844; J. Schwelle (tlk) „Mönned juttud nortele ja wannadele armsaks aja wiiteks”, 3 jagu, 1844; ,Illus Kullane Pegel”, 1847; Suve Jaan (Johann Friedrich Sommer) ,Wenne Südda ja Wenne Hing”, 1841; A. Umblia „Aboni üks karja pois ... ”, 1845; (tõlkija tiitellehel märkimata) „Mai Roos", 1865. 
ja vigaseks põlatud tallinna-eesti piiblikeel selle väljendusviisi poolest tegelikult rahvapärasem kui näiteks O. W. Masingu, K. J. Petersoni või F. R. Kreutzwaldi keel.

XIX sajandi grammatikakirjeldustes suhtuti saama-tulevikku ettevaatlikult. Eduard Ahrens kordas Hornungist saadik käibinud tõdemust, et eesti keeles väljendab olevikuvorm ka tulevikku ning vajaduse korral võib sellele lisada ainult adverbi. Võimalust moodustada tulevikku verbi saama abil ta isegi ei maininud, lisas ainult, et abiverbi võtma kasutamine tuleviku tähendusega konstruktsiooni moodustamiseks on tarbetu germanism. (Ahrens 2003 (1853): 285-286) Ka ,perifrastilisest konjugatsioonist" rääkides ei maininud ta saama + Sup -tarindeid, vaid kirjeldas ainult saama ühendeid partitsiibiga (samas: 288-291). Verbi saama tähendust analüüsides tõi ta küll tähenduste 'zu etwas kommen' ja 'Einen zu etwas bringen' illustratsioonina paar saama + Sup -tarindit, kuid osas neist on saama minevikus ning Ahrens ei seostanud neid ajakategooriaga (samas: 400-401).

F. J. Wiedemann tunnistas oma suures grammatikas, et saama abil võib eesti keeles moodustada ,üsna saksa keelega sarnase futuurumi”. Näitena tõi ta lause enne lund ei sā tänawu ohre leikama, andes sellele kaks tõlgendust: 'vor dem Schnee wird man heuer nicht zum Gersteschneiden gelangen' (mis sobiks pigem Ahrensi kirjeldatud tähendusega) ja saksa tulevikule vastavalt 'heuer wird man nicht vor dem Schnee Gerste schneiden'. (Wiedemann 2011 (1875): 528) Varasemas, ainult Võru murdele keskendunud grammatikas Wiedemann saama + Sup -tarindi saksapärast tulevikutähendust ei maininud. Seal nentis ta küll, et rahvas kasutab kõnealust konstruktsiooni (nii nagu ka partitsiibiga moodustatud saama-passiivi) palju vähem kui sakslastest kirjamehed, kuid kinnitas, et „tegelikult väljendatakse [sellega] tähendust ,millegi tegemiseks suuteline olema, mitte enese võimetuse ega ajapuuduse tõttu selles takistatud saama"'. (Wiedemann 2002 (1864): 95) Suures grammatikas viitas Wiedemann tulevikuvormist rääkides ettevaatlikult paikkondlikele erinevustele, öeldes, et seesugust futuurumit kasutatakse Kesk-Eestimaal vähem kui mujal. Aktiivse saksapärase saama + Sup -tuleviku erilise leviku kohta kirjakeeles ei pea ta vajalikuks suures grammatikas midagi öelda, ehkki passiivist rääkides rõhutab teisal, et kirja- ja kirikukeeles levib tulevikuline saab antama -tüüpi konstruktsioon. (Wiedemann 2011 (1875): $528,493)$ 
XX sajandi 30. aastatel soovitavad mõned keelekorraldajad saama-tulevikust kui saksapärasest väljendusviisist loobuda, kuid mingil määral on see keeles püsinud tänini (Tragel, Habicht 2012: 1401).

\section{Võimalikke selgitusi}

Malli saama + Sup erineval käekäigul kummaski kirjakeeles XVII-XVIII sajandil näib olevat kaks võimalikku selgitust, mis ei pruugi teineteist välistada: a) murdeline tagapõhi, b) keelevälised juhuslikud asjaolud.

Murdelisest tagapõhjast selgitusi otsides tuleb oletada, et tartu keelde jäeti saama-tulevik XVII sajandil alles sellepärast, et see mõjus seal keeleomasemalt kui tallinna keeles. See eeldaks, et lõunaeesti murretes pidi XVII sajandil kas saama + Sup -mall ise või mõni sellesarnane tuleviku tähendusega tarind olema levinum kui põhjaeesti murretes. Otseseid andmeid, mis seda kinnitaksid, on paraku raske leida. Võiks ainult oletada, et ehk oli tuleviku vormi kasutava läti keele mõjul tulevikulisuse väljendamine lõunaeesti murdeis aktuaalsem kui põhja pool. Rahvapäraste, mittetulevikulise tähendusega saama + Sup -tarindite kohta tõdeb Julius Mägiste XX sajandil, et seda laadi konstruktsioonide murdelise leviku pilt pole selge, ent need näivad olevat laialdaselt kasutusel (Mägiste 1936: 78). Ka Eesti Keele Instituudi murdesõnaraamatu käsikirja saama-tarindite näitematerjalist pole võimalik selgepiirilist murdelise leviku mustrit tuvastada.

Karl Pajusalu on oletanud, et lõunaeesti murretes leidub verbi saama leksikaalses tähenduses nüansse, mis võisid soodustada selle kasutamist tuleviku väljendamisel. ${ }^{5}$ Verbi saama funktsioneerimist tuleviku väljendajana peetakse seotuks tähendustega 'tulema' ja 'õnnestuma' ('come', 'succeed' - Tragel, Habicht 2012: 1399). Eesti Keele Instituudi murdesõnastiku käsikirja praeguses liigenduses verbi saama tähenduste juures selgeid murdelisi iseärasusi välja ei joonistu, kuid küsimus vajab kindlasti detailsemat semantilist analüüsi.

Ent isegi kui selguks, et XX sajandil talletatud materjali põhjal on verbi saama ja/või selle abil moodustatud tarindite korral tuleviku tähendus lõunaeesti murretes tõepoolest selgemini esindatud kui põhjaeesti murretes, ei saa sellest päris üheselt järeldada, et olukord XVII sajandil samasugune oli. Verbi saama potentsiaalset tuleviku tähendust võis

Siinse artikli aluseks olnud ettekande kommentaar Karl Pajusalult Huno Rätsepa juubelikonverentsil 28.12.2012. 
Lõuna-Eesti kõnekeeles võimendada just XVIII sajandi tartu kirjakeel. Nii et XVII sajandi keeleuuenduse keeleväliseid tegureid tasub igal juhul arvestada.

Olulisim keeleväline asjaolu, mis saama + Sup -tuleviku püsimist või kaotamist võis mõjutada, on tollase keeleuuenduse kronoloogiline kulg. Reform algas tartu keeles ja „Wastne Testament” ilmus 1686. On võimalik, et saama-futuurumi kaotamise idee tekkis keeleuuendajatel alles selle etalonteksti ilmumise aegu, kui parandusi ei saanud enam teha, või vahetult sellele järgnenud aastail. 1693. aastal ilmunud uuenduslikus tallinna keele grammatikas on tuleviku puudumine selgelt välja kuulutatud ja 1694. aastast pärinevas tõlkekoopias esineb saama + Sup -tulevikku tõesti väga vähe, aga J. Hornungi 1687/1688. aastal kirja pandud variandis võis see veel olemas olla.

Sellele, et saama + Sup -tulevik otsustati kirjakeelest kaotada alles XVII sajandi 90. aastate alguses, näib viitavat ka kolmas artikli alguses mainitud uuenduslik tõlketekst, oletatavasti Andreas ja Adrian Virginiuse poolt ajavahemikus 1687-1690 tõlgitud tallinnakeelne vana testament. Nagu Hornungi tõlke puhul, nii ei ole ka selle tõlke originaal säilinud, aga koopias, mida peetakse selle veidi hilisemaks ärakirjaks, on saama-tulevik igatahes täiesti tavaline: 1Ms 2:24 saap mahha jätma, 1Ms 3:15 saap ärratallama, saat pistma jne. Oma autobiograafias (1706) kirjutab Adrian Virginius: ,Mina võtsin .. 1687. aasta 20. novembril hr Johann Hornungi enda juurde Puhja, tema tõlkis kogu uue testamendi uuesti, kreeka teksti järgi tallinna-eesti keelde ja andis selle versiooni täiesti puhtaks kirjutatud eksemplarina 1688. aastal hr kindralsuperintendant Fischerile. Mina aga asusin oma õndsa isaga Vana Testamendi juurde, ja me jõudsime sellega niikaugele, et tõlkisime lõpuni pentateuhi ja teised ajaloolised raamatud kuni Iiobi raamatuni." Sellest lõigust jääb mulje, nagu oleksid Adrian Virginius, tema isa Kambja õpetaja Andreas Virginius ja Johann Hornung 1687/1688. aastal Puhjas kolmekesi koos piiblit põhjaeesti keelde tõlkinud: Hornung pani kirja keeleuuendusliku uue testamendi, Virginiused tõlkisid vana testamenti. Niisugust koostööd eeldades on raske uskuda, et samal ajal kui Virginiused vana testamendi tõlkes saama +Sup -tulevikku edasi kasutasid, redigeeris Johann Hornung seda uue testamendi tekstist välja. Saama-tuleviku kaotamine tundub olevat niivõrd radikaalne samm, et seda ei saanud teha niisama, ilma omavahel arutamata ja teadlikult sellise valiku kasuks otsustamata. Seda arvestades tundub mõistlikum oletada, et 
otsuseni saama + Sup -tulevik kui saksapärane konstruktsioon kirjakeelest välja rookida jõuti alles 1690. aastate alguses ning Müncheni käsikiri ei kajasta tuleviku vormistamisel J. Hornungi algset versiooni. Tartukeelne „Wastne Testament” oli tulevikust loobumise ajaks juba ammu ilmunud, aga ka selle teises trükis (1727) polnud uuendust võimalik teha lihtsalt seepärast, et nii keskse teksti kaudu kord juba käibesse läinud keelt ei saa nii olulistes punktides enam muuta. Tallinnakeelse uue testamendi käsikirjadesse viidi muudatus edasise töö käigus 1690. aastate alguses sisse, vana testamendi säilinud koopia võib aga pärineda mõne truu ümberkirjutaja sulest, kes keeleuuenduse ideedega nii hästi kursis polnud.

Päris kindel seesuguses asjade käigus siiski olla ei saa. Virginiustele omistatava vana testamendi tõlke koopiaga seondub mitmeid küsitavusi. Aivar Põldvee on toonud esile, et selles kasutatud kirjaviis erineb kõigist kaasaegseis tekstides kasutatuist, Heiki Reila on peale tulevikuvormide leidnud muidki olulisi keelendeid, mille poolest selle keel Müncheni käsikirja omast selgesti lahkneb. ${ }^{6}$ Eespool tsiteeritud autobiograafia lõigus ei ütle Adrian Virginius otsesõnu, missugusesse keelevarianti nad isaga vana testamenti tõlkisid. Tõdemus, et H. A. Erxlebeni poolt XVIII sajandi Iõpul välja antud tartukeelse lühendatud vana testamendi algusosa kattub Virginiustele omistatava tõlke tõlgenduste ja sõnastusega, on viinud hüpoteesini, et Virginiuste algne tõlge võis olla tartukeelne (Ross 2011). Niisugusel juhul tuleks taas mängu murdelise tagapõhja erinevus ning poleks ikkagi välistatud, et keeleuuendajad suhtusid saama + Sup -tuleviku vormidesse reformi algusest peale kummaski kirjakeeles erinevalt ning jätsid selle tartu keelde teadlikult alles, samal ajal kui nad selle tallinna keelest sihipäraselt kõrvaldasid.

\section{Kokkuvõte}

Saksapäraseks peetava saama + Sup -tuleviku käekäik oli tartu ja tallinna keeles erinev. Tallinna keelest kõrvaldati see XVII sajandi lõpukümnenditel keeleuuenduse käigus peaaegu täielikult, kuid tartu keelde jäi saama-tulevik alles ning püsis piiblitõlkes kuni viimase tartukeelse uue testamendi väljaandeni 1905. aastal. Vanema tõlkeloo senise uurituse puhul jääb lahtiseks, kas saama + Sup -tuleviku erineva kohtlemise põhjuseks oli XVII sajandi lõpu keeleuuendajate teadlik otsus, mis lähtus

${ }^{6}$ Ettekanded Eesti Keele Instituudi väliseminaril Puhjas 29.09.2012. 
põhja- ja lõunaeesti murrete erinevusest, või tuldi mõttele võõrmõjuliseks peetavast väljendusviisist loobuda lihtsalt tartu keele jaoks liiga hilja, siis kui tartukeelne uuenduslik etalontekst oli juba trükist ilmunud. Omaette küsimuseks jääb, miks saama + Sup -tulevik XIX sajandil põhjaeesti ilmalikus keeles uuesti nii jõuliselt kasutusele võeti, kuid selle selgitamine ei mahu siinse vaatluse raamidesse.

\section{Lühendid}

Ii - Iiobi raamat; Jh - Johannese evangeelium; Lk - Luuka evangeelium; 1Ms Esimene Moosese raamat; Pts - partitsiip; Sup - supiin

\section{Keelenäidete allikad}

Erxleben 1796 = tartukeelne vana testamendi tõlge raamatus: Lühhikenne Wanna Piibli-Ramat, ehk Wanna Testament nink Jummala Sädusse Sönna. Meie Tarto- nink Werro-Ma Rahwa hääs nink Jummala Tundmisse kaswatamisses neide omman Keelen lühhidelt kokkosäetu. Tarto-Linan trükkitu nink müwwa Grentsiusse man. [1796] (Välja andnud H. A. Erxleben.); http://digar.nlib.ee/digar/show/?id=100461.

Gutslaff 1647-1657 = J. Gutslaffi käsikirjaline vana ja uue testamendi tõlge; tekst saadaval Eesti Keele Instituudi eesti piiblitõlke ajaloolises konkordantsis (http://portaal.eki.ee/piibel).

IAAK 2001 = IAAK: Kristian Jaak Peterson 200. Kristian Jaak Peterson: aus Anlass seines 200. Geburtstages. Eesti Keele Instituut, Underi ja Tuglase Kirjanduskeskus. Tallinn: Eesti Keele Sihtasutus.

München 1694 = uue testamendi käsikiri; tekst saadaval Eesti Keele Instituudi eesti piiblitõlke ajaloolises konkordantsis (http://portaal.eki.ee/piibel).

Piibel 1739 = esimene eesti trükipiibel; tekst saadaval Eesti Keele Instituudi eesti piiblitõlke ajaloolises konkordantsis (http://portaal.eki.ee/piibel).

Pilistvere 1680-1687 = uue testamendi käsikirjaline tõlge; tekst osaliselt raamatus: Põhjaeestikeelsed Uue Testamendi tõlked 1680-1705. Luuka evangeelium. Apostlite teod. Koost. Kristiina Ross. Toim. Heiki Reila, Kristiina Ross, Kai Tafenau. [Eesti Keele Instituut] Tallinn: Eesti Keele Sihtasutus.

Rossihnius 1632 = J. Rossihniuse välja antud perikoobid; tekst saadaval Eesti Keele Instituudi eesti piiblitõlke ajaloolises konkordantsis (http://portaal. eki.ee/piibel).

Stahl $1638=$ H. Stahli välja antud perikoobid; tekst saadaval Eesti Keele Instituudi eesti piiblitõlke ajaloolises konkordantsis (http://portaal.eki.ee/piibel). 
VAKKUR = Tartu Ülikooli vana kirjakeele korpus; http://www.murre.ut.ee/vakkur/Korpused/korpused.htm.

Virginiused 1687-1690 = Andreas ja Adrian Virginiuse tõlgitud käsikirjalise vana testamendi oletatav koopia; tekst saadaval Eesti Keele Instituudi eesti piiblitõlke ajaloolises konkordantsis (http://portaal.eki.ee/piibel).

WT 1686 = tartukeelne, ,Wastne Testament”; tekst saadaval Eesti Keele Instituudi eesti piiblitõlke ajaloolises konkordantsis (http://portaal.eki.ee/piibel).

WT 1905 = Meie Issanda Jesuse Kristuse Wastne Testament ehk Wastse Lepingo Raamat nink Kuninga Tawida Laulu-Raamat. Jurjew (Tarto): Schnakenburg'i man trükkitu.

\section{Kirjandus}

Ahrens, Eduard 2003 (1853). Eesti keele Tallinna murde grammatika. - Uue ajastu misjonilingvist. Eduard Ahrens 200. Koost. ja toim. K. Ross. [Eesti Keele Instituut]. Tallinn: Eesti Keele Sihtasutus, 75-429.

Gutslaff, Johannes 1998 (1648). Observationes grammaticae circa linguam esthonicam. Grammatilisi vaatlusi eesti keelest. Tõlk. ja väljaande koost. Marju Lepajõe. Toim. Jaak Peebo. (= Tartu Ülikooli eesti keele õppetooli toimetised 10.) Tartu: Tartu Ülikool.

Hornung, Johann 1977 (1693). Grammatica Esthonica, brevi, Perspicua tamen methodo ad Dialectum Revaliensem. Eingeleitet und herausgegeben von Harald Haarmann. (= Die estnischen Grammatiken des 17. Jahrhunderts 3. Fenno-Ugrica 4). Hamburg: Helmut Buske Verlag.

Kask, Arnold 1970. Eesti kirjakeele ajaloost I. [Tartu Riiklik Ülikool. Eesti keele kateeder.] Tartu.

Kilgi, Annika 2010. Tuleviku tulekust: tulevikulisuse väljendamisest meie esimestes piiblitõlgetes. - Keele rajad. Pühendusteos professor Helle Metslangi 60. sünnipäevaks. (= Eesti ja soome-ugri keeleteaduse ajakiri 1-2.) Tartu: ESUKA - JEHUL, 163-185.

Kilgi, Annika 2011. Anton Thor Helle toimetajakäekiri: kuidas Thor Helle vana testamendi verbimorfoloogiat redigeeris. - Emakeele Seltsi aastaraamat 56 (2010). Peatoim. Mati Erelt. Tallinn: Eesti Teaduste Akadeemia Kirjastus, 91-108. http://dx.doi.org/10.3176/esa56.04.

Laanekask, Heli 2001. Ensimmäisen eteläviron kirjakielen loppuvaiheista. Tutkielmia vähemmistökielistä Jäämereltä Liivinrantaan. Vähemmistökielten tutkimus- ja koulutusverkoston raportti III. Toim. N. Määttä, H. Sulkala. (= Suomen ja saamen kielen ja logopedian laitoksen julkaisuja 20.) Oulu: Oulun yliopisto, 117-131.

Laanekask, Heli 2003. Tartu ja tallinna keel 17. sajandi Liivimaal. - Õdagumeresoomõ hummogupiir'. Läänemeresoome idapiir. Toim. Karl 
Pajusalu, Jan Rahman. (= Võro Instituudi toimõndusõq 15.) Võro: Võro Instituut', 112-128.

Metslang, Helle 1994. Eesti ja soome - futuurumita keeled? - Keel ja Kirjandus 9, 534-547; 10, 603-616.

Mägiste, Julius 1936. Eesti saama-futuuri algupärast ja tarvitamiskõlblikkusest. - Eesti Keel 3, 65- 92.

Pahtma, Leino, Kai Tafenau 2003. Saateks. - Piiblikonverentsid ja keelevaidlused. Põhjaeestikeelse Piibli tõlkimise ajaloost (1686-1690). Allikapublikatsioon. Koost. Leino Pahtma, Kai Tafenau. Toim. Jürgen Beyer. (= Ex fontibus archivi historici Estoniae 1.) Tartu: Eesti Ajalooarhiiv, 9-14.

Peebo, Jaak 2001. Wastse Testamendi lugu. Eesti Keele Sihtasutus.

Reila, Heiki 2007. Müncheni käsikirjast ja selle seostest Johann Hornungi tõlkega. - Põhjaeestikeelsed Uue Testamendi tõlked 1680-1705: Luuka evangeelium. Apostlite teod. Koost. Kristiina Ross. Toim. Heiki Reila, Kristiina Ross, Kai Tafenau. [Eesti Keele Instituut] Tallinn: Eesti Keele Sihtasutus, 556-563.

Ross, Kristiina 2003. Saateks. - Esimene Moosese raamat. Iiobi raamat. Tõlkinud 1687-1690 Andreas ja Adrian Virginius. [Eesti Keele Instituut] Tallinn: Eesti Keele Sihtasutus, 5-21.

Ross, Kristiina 2011. Sisaliku jäljed piiblitõlkes: Lõunaeestikeelse Vana Testamendi saatusest. - Keel ja Kirjandus 8/9, 600-613.

Ross, Kristiina 2013. Johannes Gutslaffi piiblitõlge ja lõunaeesti kirjakeel. Johannes Gutslaffi piiblitõlge 1647-1657. Koost. Maeve Leivo, Ahti Lohk, Kristiina Ross, Kai Tafenau. Tallinn: Eesti Keele Sihtasutus, 475-484.

Tafenau, Kai 2007. Pilistvere käsikirjadest ja nende seosest Heinrich Göseken vanema käsikirjaga. - Põhjaeestikeelsed Uue Testamendi tõlked 16801705: Luuka evangeelium. Apostlite teod. Koost. Kristiina Ross. Toim. Heiki Reila, Kristiina Ross, Kai Tafenau. [Eesti Keele Instituut] Tallinn: Eesti Keele Sihtasutus, 551-555.

Tafenau, Kai 2011. Diskussionen über die estnische Schriftsprache in der zweiten Hälfte des 17. Jahrhunderts: Argumente und Beispiele. - Linguistica Uralica 2, 130-143. http://dx.doi.org/10.3176/lu.2011.2.05.

Tragel, Ilona, Külli Habicht 2012. Grammaticalization of Estonian saama 'to get'. - Linguistics 50 (6), 1371-1412.

Virginius, Adrian 1706. Curriculum Vitae Adriani Verginii, Pastoris in Odenpaeh, descriptum Dorpati Anno 1706. d. 9 April. - Beweise zur Livländischen Adelsgeschichte. Dritter Theil. Gesammelt von Friedrich Konrad Gadebusch (LVVA ${ }^{7}$, f 214, n 6, s 144a/12, 1 320-340). Tõlk. Kai Tafenau. Käsikiri.

${ }^{7}$ LVVA = Latvijas Valsts vēstures arhīvs (Läti Riiklik Ajalooarhiiv), Riia. 
Wiedemann, Ferdinand Johann 2002 (1864). Uurimus Võru murdest. Versuch ueber den werroehstnischen Dialekt. Tõlk. Inge Annom. Toim. Külli Habicht, Karl Pajusalu. (= Tartu Ülikooli eesti keele õppetooli toimetised 20.) Tartu.

Wiedemann, Ferdinand Johann 2011 (1875). Eesti keele grammatika. Tõlk. Heli Laanekask. Toim. Ellen Niit. Tallinn: Eesti Teaduste Akadeemia Emakeele Selts. 


\title{
Old innovations in South and North Estonian
}

\author{
Kristiina Ross
}

The article focuses on the fate of the future construction /saama 'become' + INF2/ in the two varieties of Old Written Estonian during the language reform at the end of the 17th century. The construction exactly corresponds to the respective (High) German construction and is generally believed to have been borrowed (ich werde lesen $\rightarrow$ mina saan lugema) although there are some similar constructions in Finnic languages as well. The construction was common in the most important text of Old South Estonian (New Testament 1686), and in Literary South Estonian it was actively used until the extinction of this variety at the beginning of the 20th century. As for Old North Estonian, the construction was excluded during the 17th-century reform. It was not used in the first complete Estonian Bible (1739), and North Estonian authors of the 18th century deliberately avoided it. In the 19th century the construction again became frequent in Literary North Estonian. It is argued whether the destiny of the construction in the two varieties was due to differences between South and North Estonian dialects or whether it was simply the result of chronological extra-linguistic circumstances of the language reform.

Keywords: history of Standard Estonian, Literary South Estonian, Literary North Estonian, future

Kristiina Ross

keeleajaloo ja -teaduse osakond

Eesti Keele Instituut

Roosikrantsi 6

10119 Tallinn

Kristiina.Ross@eki.ee 